EESTI NSV TEADUSTE AKADEEMIA TOIMETISED. XVII KÖIDE KEEMIA* GEOLOOGIA. 1968, Nr. 3

ИЗВЕСТИЯ АКАДЕМИИ НАУК ЭСТОНСКОН ССР. ТОМ XVII

ХИМИЯ * ГЕОЛОГИЯ. 1968, № 3

К. УТСАЛ

\title{
О ГЛИНИСТЫХ МИНЕРАЛАХ СРЕДНЕДЕВОНСКИХ ОТЛОЖЕНИЙ ЭСТОНИИ
}

K. UTSAL. KESKDEVONI SAVIMINERAALIDEST EESTIS

K. UTSAL. ABOUT THE MIDDLE DEVONIAN CLAY MINERALS OF ESTONIA

До последнего времени глинистые минералы среднедевонских отложений детально не исследовались. Автором изучены рентгеновским методом глинистые минералы кернов 13 буровых скважин и ряда обнажений (см. рис. 1). Разрезы буровых скважин частично или полностью захватывают среднедевонские отложения Эстонии. На основании полу-

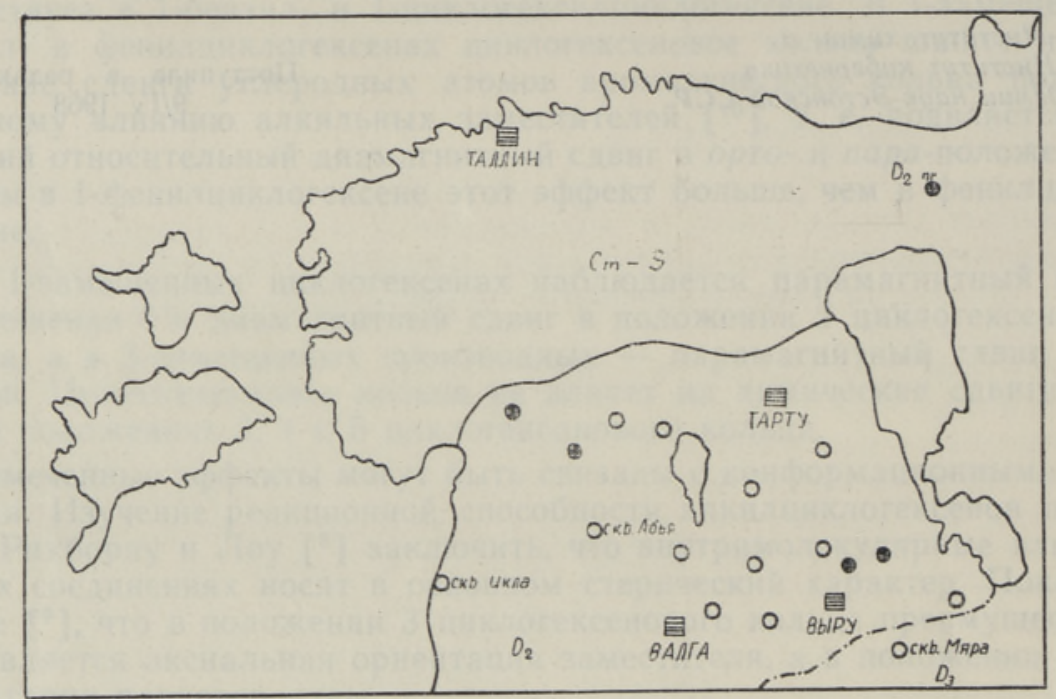

Рис. 1. Схема выхода среднедевонских отложений Эстонии: Черные кружки - обнажения. белые - буровые скважины, где отобраны пробы для анализа; пунктир - южная граница среднедевонских отложений, сплошная линия - северная граница девонских отложений.

ченных данных (более 1500 образцов) приводится общая характеристика глинистых минералов по отдельным горизонтам или слоям (см. рис. 2).

Среднедевонские отложения Эстонии расчленяются на следующие горизонты (снизу вверх): пярнуский $\left(\mathrm{D}_{2} \mathrm{pr}\right)$, наровский $\left(\mathrm{D}_{2} \mathrm{nr}\right)$ и тартуский с буртниекскими $\left(\mathrm{D}_{2} \mathrm{tr} \mathrm{br}\right)$ и арукюласкими $\left(\mathrm{D}_{2}\right.$ tr $\left.\mathrm{ar}\right)$ слоями.

П я р н уск и й го р и зон т представлен главным образом пестроцветными песчаниками; реже здесь присутствуют мергели, доломиты и глины. Мощность его доходит до $90 \mathrm{M}$. Доминирующим глинистым минералом в пярнуском горизонте является диоктаэдрическая гидрослюда. В качестве примеси в этом горизонте присутствуют хлорит и каолинит. 
Нижняя часть н аров с кого горизонта состоит из серых мергелей и доломитов с прослоями глин и песчаников; в основании залегает брекчия из обломков карбонатных пород. В доломитовых мергелях присутствуют впервые установленные в Эстонии неупорядоченные и упорядоченные смешанно-слойные глинистые минералы типа монтмориллонитахлорита.

В юго-восточной части Эстонии в пределах этого горизонта смешанно-слойные образования менее развиты (скв. Мяра). В большем количестве они встречаются в западных районах (скв. Икла и Абья). В разрезах этих скважин можно проследить последовательную смену (снизу вверх) следующих глинистых минералов: хлорит $\rightarrow$ неупорядоченный монтмориллонит-хлорит $\rightarrow$ упорядоченный монтмориллонит-хлорит $\rightarrow$ неупорядоченный монтмориллонит-хлорит $\rightarrow$ хлорит.

В верхней части наровского горизонта обычно присутствует только гидрослюда с примесью хлорита и каолинита. Исключением является скв. Икла, где смешанно-слойные образования имеют два максимума развития в верхней и нижней частях горизонта.

В верхах горизонта преобладают буровато-красные косослоистые алевриты. Мощность наровского горизонта достигает $86 . \mu$.

А рукюлаские слои та р туского гори $з$ он т а представлены в основном крас-

Рис. 2. Сводный разрез среднедевонских отложений Эстонии с характерными дифрактограммами глинистых минералов:

1 - брекчня; 2 - песчаник; 3 - алевролит; 4 - глина; 5 - доломитовый мергель; 6 - доломит.

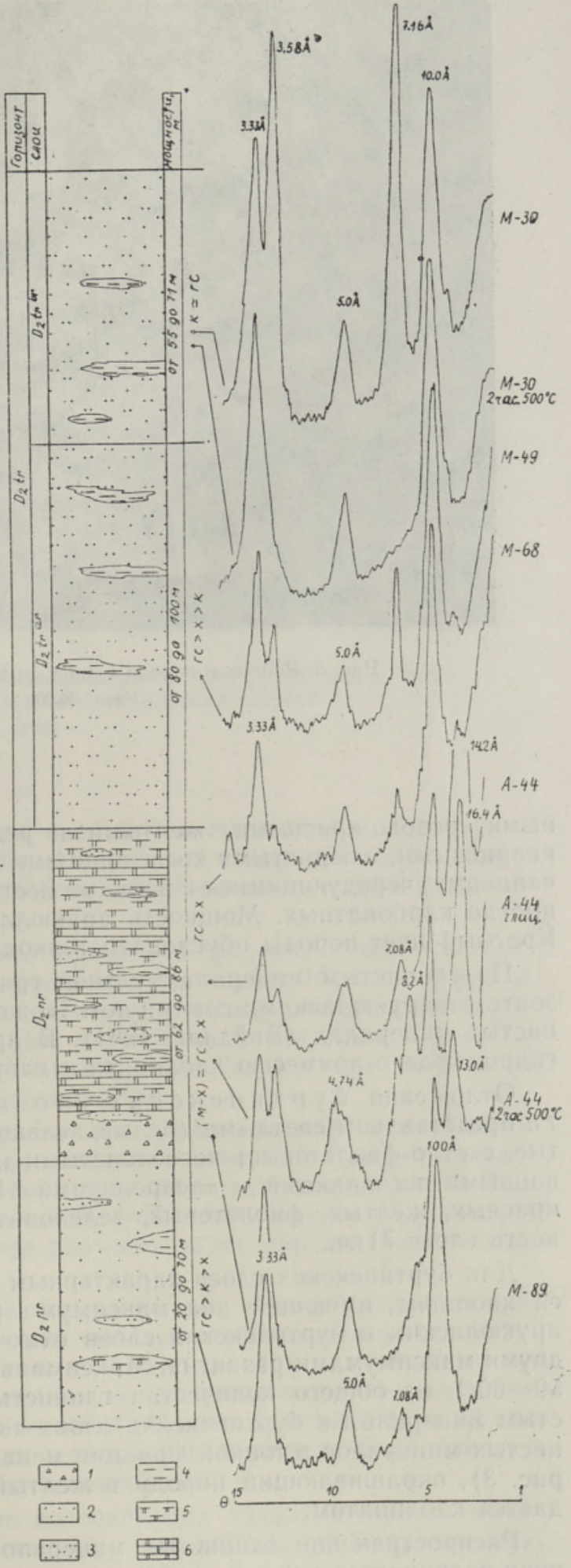




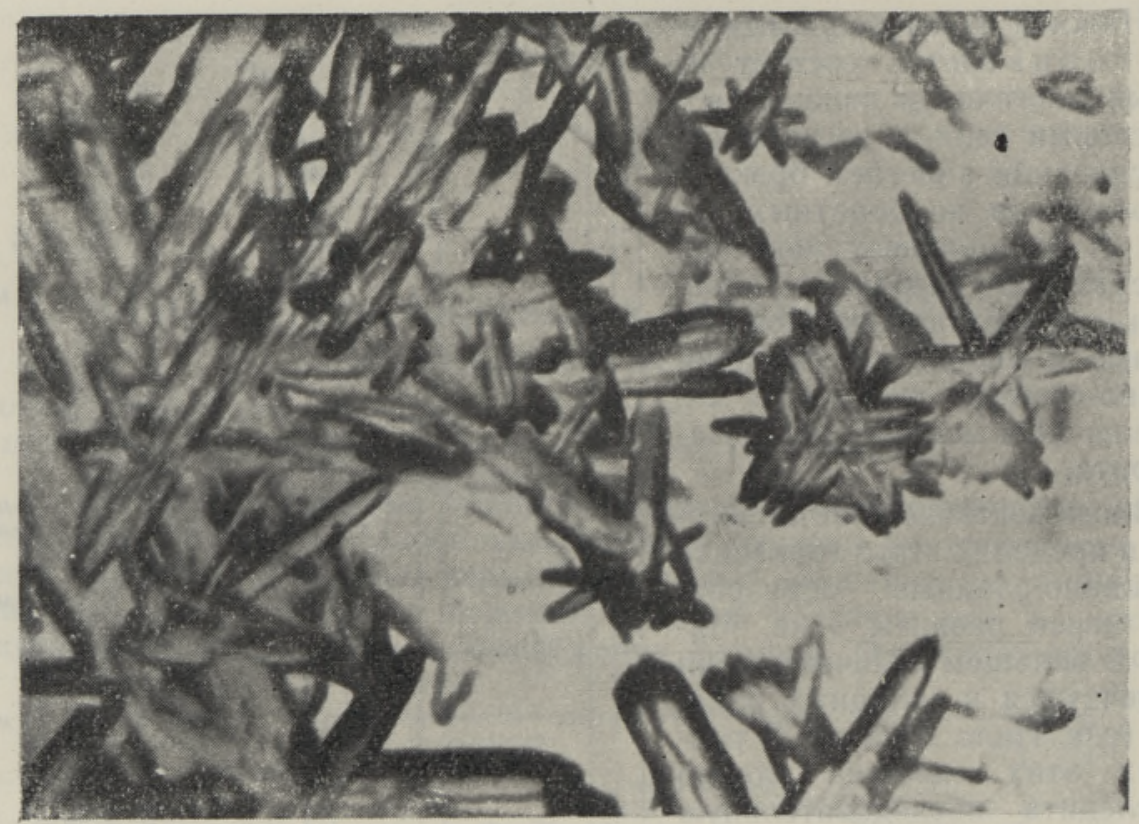

Рис. 3. Реплик с оскола глины; видны звездочки гетита. увел. $30000 \times$.

ными, розово-красными, желтыми и редко белыми мелкозернистыми кварцевыми, слюдистыми косослоистыми слабо сцементированными песчаниками, чередующимися с пачками пестрых алевритов и красных глин, иногда карбонатных. Мощность арукюласких слоев доходит до $100 \mathrm{M}$. Красный цвет породы обусловлен тонкодисперсным гематитом.

По глинистым минералам резкой границы между наровским горизонтом и арукюласкими слоями нет. То же самое можно сказать о неглинистых минералах (Вийдинг, 1964). В арукюласких слоях доминирует гидрослюда с примесью каолинита и хлорита.

Отложения буртни екких слоев тартуского горизон т а представлены светлыми (белые, зеленовато-желтовато-серые, розоватые, светло-фиолетовые) косослоистыми кварцевыми слабо сцементированными песчаниками и алевролитами. Нередки прослойки и линзы красных, желтых, фиолетовых, зеленовато-серых и серых глин. Мощность слоев $71 \mathrm{M}$.

Для буртниекских слоев характерным глинистым минералом является каолинит, имеющий два максимума распространения. На границе арукюласких и буртниекских слоев отмечается появление каолинита с двумя максимумами развития. Максимальное содержание его составляет $50-60 \%$ от общего количества глинистых минералов. Другим глинистым минералом в буртниекских слоях является гидрослюда. Из неглинистых минералов в тонкой фракции меньше $1 \mu$ присутствует гетит (см. рис. 3), окрашивающий породу в желтый цвет. Нередко он сопровождается каолинитом.

Распространение глинистых минералов в среднедевонских отложениях подчиняется определенной закономерности: в песчанистых породах 


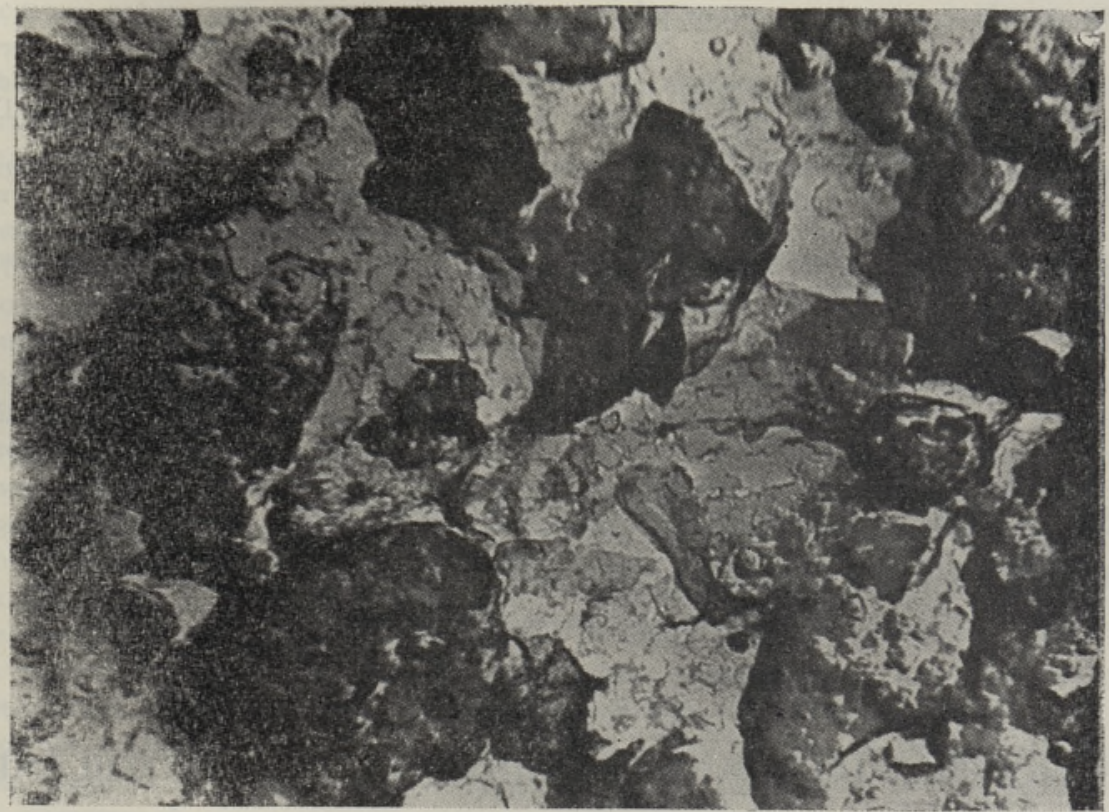

Рис. 4. Реплик с поверхности ориентированного препарата; видны неправильные формы частиц монтмориллонит-хлорита.

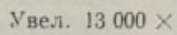

(буртниекские слои) встречаются каолинит и гидрослюда, в то время как карбонатные породы (наровский горизонт) содержат, кроме гидрослюды, еще хлорит и смешанно-слойные образования типа монтмориллонита-хлорита.

Изученные гидрослюды разных горизонтов среднего девона мало отличаются друг от друга. Все они относятся к политипу $1 \mathrm{Md}$. Электронномикроскопические исследования показали, что гидрослюды имеют изометрическую форму с максимальным диаметром частиц около $0,3-0,5 \mu$. Такая форма частиц гидрослюд может в ряде случаев указывать на их аллотигенное происхождение (Ратеев, 1964).

Следует отметить, что размеры частиц каолинита всегда превышают размеры гидрослюды (от 1 до $2 \mu$ ) и поэтому дают более узкие площади рефлексов (001) на дифрактограммах ориентированных препаратов. Возможно, что каолинит среднедевонских отложений имеет аллотигенное происхождение, будучи продуктом размыва ранее образовавшейся каолинитовой коры выветривания.

Смешанно-слойные глинистые минералы типа монтмориллонита-хлорита в наровское время образовались в лагунных условиях, когда избыток $\mathrm{Mg}$, по-видимому, воздействовал на гидрослюду и, возможно, на каолинит, которые могли переходить в монтмориллонит-хлоритовые минералы с различной упорядоченностью структуры, т. е. последние можно считать новообразованиями. Количество монтмориллонитовых слоев в структуре монтмориллонит-хлорит достигает $40 \%$.

Электронно-микроскопические исследования таких глинистых минералов, проведенные автором, показали, что они имеют неправильную агрегатную форму (см. рис. 4). 